\title{
Teacher's experiences in character education for autistic children
}

\author{
Hanif Cahyo Adi Kistoro', Caly Setiawan², Eva Latipah ${ }^{3}$, Himawan Putranta ${ }^{4}$ \\ ${ }^{1,2}$ Department of Educational Research and Evaluation, Graduate School, Universitas Negeri Yogyakarta, Yogyakarta, \\ Indonesia \\ ${ }^{1}$ Department of Islamic Education, Faculty of Islamic Studies, Universitas Ahmad Dahlan, Yogyakarta, Indonesia \\ ${ }^{3}$ Department of Islamic Education, Faculty of Education and Teaching Science, Universitas Islam Negeri Sunan Kalijaga, \\ Yogyakarta, Indonesia \\ ${ }^{4}$ Concentration of Physics Education, Department of Educational Sciences, Graduate School, Universitas Negeri \\ Yogyakarta, Yogyakarta, Indonesia
}

\begin{abstract}
Article Info
Article history:

Received May 23, 2020

Revised Dec 14, 2020

Accepted Jan 27, 2021

\section{Keywords:}

Autism

Character education

Explanatory

Intensive mentoring

Practice

ABSTRACT

Character education is also important given to autistic children. This phenomenological research aims to reveal the teacher's experience in teaching character education for autistic children. The participants in this research were 10 teachers from three exceptional schools consisting of public and private exceptional schools. In-depth interview method as a data collection technique. Data analysis using semantic reduction is carried out by the stages of identifying important statements from the results of the interview, determining the theme of the discussion, and describing the significance of the whole the teacher's experience. The results found that character learning for autistic children through three models, namely explanatory, practice, and intensive mentoring. The explanatory model is used to practice the ability of autistic children in terms of building children's concentration and focus. The practice model is used to train autistic children soft skills in terms of strengthening the understanding of the material and its reasoning ability. While the intensive mentoring model for training soft skills autistic children related to the ability of interpersonal relationships and confidence. Therefore, the inclusion of teacher competencies must at a minimum include pedagogical, personal, and social abilities to teach character education for autistic children.
\end{abstract}

This is an open access article under the CC BY-SA license.

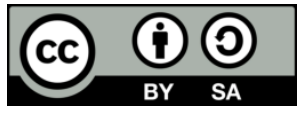

\section{Corresponding Author:}

Hanif Cahyo Adi Kistoro

Department of Educational Research and Evaluation

Graduate School

Universitas Negeri Yogyakarta

Jalan Colombo No. 1, Yogyakarta 55281, Indonesia

Email: hanifcahyo.2018@student.uny.ac.id

\section{INTRODUCTION}

The basic aim of education is to optimize children's abilities in the learning process in an integrated and systematic way. Education in accordance with the mandate of the Constitution in Indonesia is a human right for everyone. This means that everyone has the right to get proper education in their lives. From this understanding, education is a conscious act with the aim of preserving and developing human nature and potential towards the formation of whole people [1]. However, not all children get proper education in the field. This can be due to individual abilities or other things from the external side. In terms of ability, each 
child has its own characteristics, both physically and intelligence. There are children with complete abilities who can receive learning well [2]. Not a few children born have limitations either physically or mentally. On the other hand, education also has its own problems in the implementation process. There is a provision from the school's obligation to accept all school students regardless of conditions. This is marked by the number of inclusion children, in this case autistic children studying in public schools [3]. Schools must be ready and able to develop the abilities of all these students. Schools are then expected to be able to apply learning models that can accommodate the needs of normal children and special needs.

The obligation to provide special education is also in accordance with Constitution of the Indonesia Republic Number 20 of 2003 concerning the national education system article 5 paragraph 2 states that citizens who have physical, emotional, mental, intellectual and/or social disabilities are entitled to special education [4]. The explanation of this article is that special education is education that is adjusted to the abnormalities of students regarding the implementation of the education in question. Schools that can accept students with special needs are schools that hold inclusive learning, where students with special needs get the same educational rights as students in general. Education must provide special access for autistic children even to the highest level of education [5]. One category of children who have limitations is autistic children. Autistic children as an example of children who experience communication problems in the education process are usually caused by a disruption in language. Autistic children are not without the ability to communicate, it's just that they have limitations in the communication process [6]. In general, autistic children tend to limit themselves and are more interested in their own world, thus ignoring social contact with the wider community. In this condition, parents have obligations and important roles in assisting their development at home [7].

Basically, a diagnosis of autism means that an individual has impaired ability to communicate and acquire social skills. Usually associated with children in the early stages of social development [8]. A characteristic associated with autism is repetitive self-stimulating behavior, called stimming. The most common examples are rocking, pacing, repetitive words, piling up objects, and banging his head. Compared with children who normally develop normally, autistic children have a tendency to be alone and enjoy solitude [9]. Autistic children can be friends with at least one person, but the quality of their friendship is not good in terms of safety and mentoring [10]. Unlike exceptional schools, in autistic exceptional schools must adjust to the conditions experienced by students. The communication system implemented in autistic exceptional schools, especially between teachers and students, must use a unique method. This is caused by factors students who experience obstacles in the development of the language, so it is less able to receive information or messages well [11]. Special education for autistic people is not much different from education in general. However, the curriculum needs to be specifically designed, because the general education curriculum is not suitable for autistic people. Therefore, teachers are required to be able to modify the curriculum that is tailored to student conditions and improve the quality of professionalism [12]. Special education is also prioritized, because teachers are the main source of knowledge possessed by autistic children. Teachers must have a high level of creativity and have an open heart in providing services to autistic children, and must be supported with adequate resources so that the creativity of the teacher can be realized.

In addition to problems in the learning process, learning material also influences the teacher's methods and strategies used. In accordance with the curriculum, religious education material as learning material for student characters also becomes mandatory material for autistic students [13]. That is because religious education is the main foundation in life for every human being. Religious education in schools must be adjusted to the diversity of religions in Indonesia, so that every child has the right to obtain religious knowledge in accordance with the beliefs held $[14,15]$. It is this ability in religious education material that fosters and strengthens student character. Zidny, et al. [16] mentioned the goal of contemporary Islamic education, not only changing the socio-cultural and knowledge base of students, but also Islamic education is expected to be able to solve the moral and ethical problems of modern science.

The existence of religious education aims to instill faith and piety in each individual, as well as shape human morals so that individuals become noble and virtuous individuals in accordance with Islamic religion. A deep understanding of religious teachings will affect the attitudes and behavior of individuals in everyday life. A religious teaching can be accepted and understood if it is delivered with good communication, especially for children with special needs even though patience is needed from the educator. Inclusive teachers who teach for children with special needs, are one of the important elements in success in character education for autistic children [17]. Therefore, inclusive teachers must be equipped with pedagogic abilities and other abilities. The reality on the ground is that there are serious problems in terms of teacher competency. Many teachers who are not formally competent have received special education in inclusive schools [18, 19]. However, their years of experience in teaching became a provision because of the 
limitations of existing teachers. The existence of these conditions makes teachers are required to be creative in being able to carry out learning well.

Autism itself is a term used for a condition that is generally considered a developmental disorder for certain children [5]. Autism is a complex neurological disorder characterized by limited communication skills, social anxiety, and typical behavior [3]. Nearly all autistic children have the same four characteristics: preference for solitude, insistence on similarity, fondness for complex routines and some abilities that seem extraordinary [20]. Another characteristic of autistic children is the behavior of repetitive self-stimulation, called stimming. The most common examples are rocking, pacing, repetitive words, piling up objects, and banging one's head [21]. The historical record of autism in modern textbooks almost always begins with Leo Kanner's report of 11 children with a series of symptoms that came to be called autism [22]. In his classic book, Haslam, et al. [23] portrays a 7-year-old boy with delayed language, disruption of socialization, and preoccupation. At age 13, the boy showed improvement in language, but only spoke in short sentences, often mentioned his name, engrossed in his own world and repeated his words. In the early days, researchers did not use the word autism for children who have this problem, but they provided detailed case descriptions of children with little or no language, limited interactions with others, living in their own world, and exhibited stereotypical movements [22].

The teacher needs to identify whether teaching can be given independently by mentoring or collectively. Therefore, it can be understood that the ability of teachers to teach autistic children must be balanced with skills in teaching, communication, and creativity. During the learning process, autistic children can also be directed through the manipulation of classroom organizations, management procedures in education, teaching staff ratios, curriculum, and parental involvement [24]. In the context of education in Indonesia, departments in various universities to produce inclusive teachers have begun to develop. The output of this graduate is expected to provide answers to the demands and educational needs of inclusive children in this modern era, especially in character education.

In this research, several important and new themes can be identified. First, there is a need for the number of inclusive schools, both public and private, which do not match the number of students with special needs. Second, there are still a few teachers specifically for inclusive education graduates. Third, there is an increase in teacher competence obtained from training and workshop activities, especially for teachers who are not graduates of inclusive schools. Fourth, the creativity and innovation abilities of teachers are one of the factors supporting the success of teachers in the teaching and learning process for inclusive children. Teachers can adjust the conditions and abilities of students with the learning methods used.

Inclusive school teachers in the learning process in class are required to have sufficient competence. The minimum competencies possessed are pedagogic competencies, professional competencies, personality competencies, and social competencies. However, in reality the competencies of teachers in inclusive schools are still low [25]. This is because inclusive schools do not have special teachers from inclusive department graduates. The demand for learning for children with special needs finally the school gave the task to the teacher who was considered capable and approached his competence to be able to provide learning to autistic students. On the other hand, these deficiencies will negatively impact schools to achieve the desired educational goals. The existence of this problem makes the teacher in charge of teaching for autistic children try to be creative in the learning process for the achievement of school education goals. Teachers' experience in teaching will be revealed in this research.

Realizing the importance of competence for inclusive teachers and their role in improving the quality of education, this research will specifically examine the competency model that must be possessed by teachers in inclusive schools. This research tries to answer the following question: 1) What are the minimum types of competencies that inclusive teachers must have? 2) How do teachers teach character education for autistic children?

This phenomenological research will illustrate the experience of inclusive teachers in the process of character education for autistic children. The competencies referred to in this research are general competencies that must be possessed by a teacher in accordance with the Indonesian education constitution which includes pedagogical competencies, personal competencies, social competencies, and professional competencies.

\section{RESEARCH METHOD}

\subsection{General background}

This type of research is a qualitative research with a transcendental phenomenological approach [26]. This research was conducted to explore more information about the experience of teachers in implementing learning for autistic children. Specifically, this research aims to gain a deep understanding of how to teach teachers in inclusive schools and what types of competencies that inclusion teachers must have. This research was conducted for three months from September to December 2019. This research is expected 
to be the basis for further research development, especially for research on learning themes for autistic children who are more qualified and sustainable.

\subsection{Participant}

Participants in this research were 10 teachers from three inclusive schools in Yogyakarta, Indonesia. The selection of 10 participants is based on a research design according to Creswell [27] that the exploration of phenomena can be carried out on heterogeneous participants between 3-15 people. Three school names that are the subject of the research are mentioned with the initials I1, I2, and I3. The purpose of a disguised identity is to protect and maintain the privacy of the subject. Before taking the research data, the researcher contacted the inclusive schools that were planned to be involved in this research including the teachers. Researchers carry out this stage to obtain approval and facilitate the process of retrieving data. The researcher chose three inclusive schools as a research sample, not only because the school is administratively an exceptional school for children with special needs, but in character also represents a number of exceptional schools in Yogyakarta. In detail, the characteristics of autistic children from the three inclusive schools used in this research are shown in Table 1.

Table 1. Participants profile from three inclusive schools

\begin{tabular}{ccccccc}
\hline \multirow{2}{*}{ Inclusive school } & \multicolumn{2}{c}{ Primary school } & \multicolumn{3}{c}{ Junior high school } & \multirow{2}{*}{ Total } \\
& Male & Female & Male & Female & \\
\hline I1 & 1 & 1 & 1 & 1 & 4 \\
I2 & - & 1 & 1 & 1 & 3 \\
I3 & - & 1 & - & 2 & 3 \\
\hline
\end{tabular}

\subsection{Instrument and procedures}

The research data collection was carried out by in-depth interview techniques [27]. The duration of the interview is around 45 to 60 minutes. Interviews were conducted at the location of the inclusive school with consideration to get good quality interviews. Interview questions are open and general that are arranged by researchers to uncover the core phenomena of research [28]. Researchers also try to create a conducive atmosphere so that participants can answer freely and comfortably every question asked [26].

\subsection{Data analysis}

Data reduction based on participants' experience becomes an important part of data analysis. To get quality data, several stages are carried out, namely classifying important statements in the main theme, and describing the meaning of the experience of the phenomenon as a whole. The essence of the description is what is being experienced and how individuals deal with this experience [26]. The data analysis procedure in this research began by converting the recorded sound from the interview into a transcript, so that it could easily examine information contained. The researchers carefully read the interview transcript several times. Along with this process, researchers also choose the important information contained in it to be an important statement. Important statements identified by the researchers are further grouped into central themes. This important statement and central theme are then used to make a texture description, which is a description of what the participants experienced. Important statements and central themes are also used by researchers to make structural descriptions, namely descriptions of how participants experience the phenomenon. The final step in the data analysis procedure is writing the essence of all phenomena experienced by the participants. Essence description is a combination of texture and structural description that reveals the essence of the phenomenon experienced by the participants.

\section{RESULTS AND DISCUSSION}

In accordance with the provisions of the directorate for the development of special education and special services in Indonesia, the education services for children with special needs include material on the development of mobility, social, and communication orientation [29]. Meanwhile, a general description of the implementation of the autistic children character education system in Indonesia is presented in Figure 1.

In the application of character education for autistic children, the learning model that is carried out combines explanatory, practices, and intensive mentoring. A teacher revealed that, "Learning for autistic children ideally require special mentoring, but because there are quite a lot of students in the school, mentoring will be done after learning is finished." Another teacher also added that, "In special schools' children with needs consist of students who have different mental disorders, some are autistic, some are slow 
learners or others." Additional information was conveyed by one teacher also in his interview, "In addition to having good communication skills in learning for autistic children, creativity is also needed in teaching."

In learning about character education there are some important things that need to be considered, namely communication skills, creativity in teaching, continuous practice, and intensive mentoring. In addition to providing material, autistic students also need to be given practice in particular to strengthen the material provided. The ability in practice is specifically given to the task of students' reading, writing and thinking abilities. In addition to the practice carried out in the learning process, mentoring is an important strategy in the character education process for autistic students. Mentoring is intended to provide a sense of closeness and comfort of students in the learning process. It is known children with special needs have limitations in understanding, communication and behavior. Mentoring will help students feel someone is protecting and paying attention. This was reinforced by one teacher who stated that, "Autistic children tend to have different behaviors; they have difficulty communicating and interacting, so teachers must be able to follow their wishes in the form of mentoring."

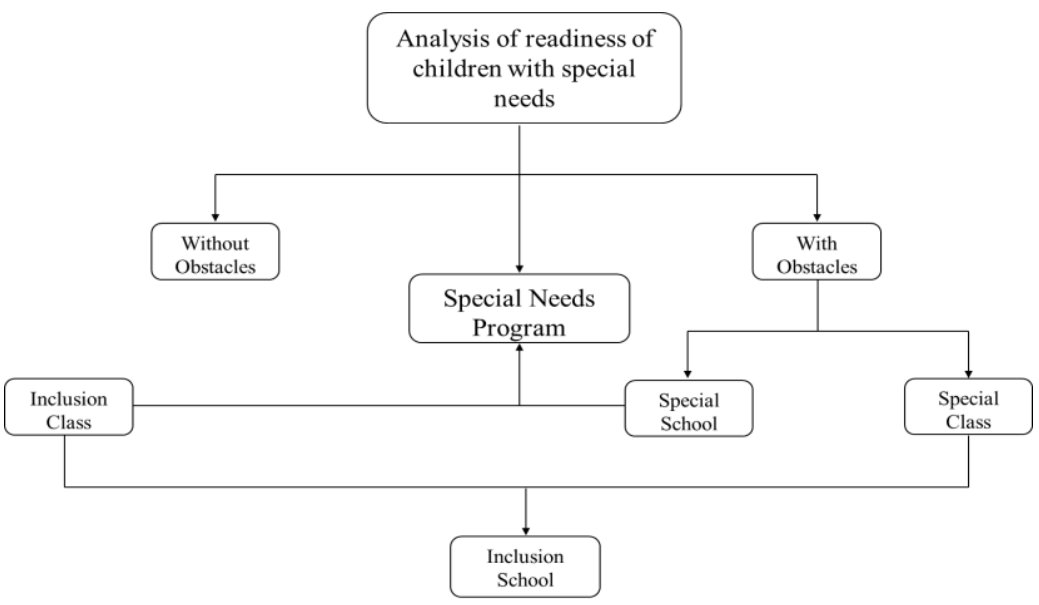

Figure 1. Overview of the autistic children character education system in Indonesia

\subsection{The teacher competence in character education for autistic children}

The important meaning in the competencies that must be possessed by a teacher in an inclusive school is how so that the character education material in this case religious material can be understood by students. Therefore, it needs good skills to be able to carry it out. Based on constitution Number 14 of 2005 concerning Teachers and Lecturers in article 10, first paragraph stated that teacher competency as referred to in Article 8 include pedagogical competencies, personality competencies, social competencies, and professional competencies obtained through professional education [30]. These teacher competency standards cover the core competencies of teachers developed into the competencies of kindergarten teachers, elementary school teachers, and subject teachers in elementary, junior high school, senior high school, and vocational high schools. Therefore, in general this competency also applies to inclusive school teachers. This was also reinforced by the opinion of one of the inclusion teachers who stated that, "Becoming an ideal teacher should be able to everything, both about how to teach, the material, communication, and become an example for students."

\subsection{Pedagogical competence}

Pedagogical competence is the ability of understanding of students, the design and implementation of learning, evaluation of learning outcomes, and the development of students to actualize the various potentials they have. Sub competence in pedagogical competence is to understand the condition of students in depth which includes understanding the principles of cognitive development, the principles of personality, and identifying students' early learning provisions. One of the teachers said that, "My experience in teaching for many years, the main thing first was to know the ability of students, so we will be able to make a teaching strategy." In the pedagogical ability, teachers are expected to be able to design learning, including understanding the educational foundation for the benefit of learning which includes understanding the educational foundation, applying learning and learning theories, determining learning strategies based on learner characteristics, competencies to be achieved, and teaching material, as well as preparing learning designs based on the strategy chosen. 
In addition, the teacher is also expected to be able to carry out learning which includes arranging the learning background and carrying out conducive learning, able to design and carry out learning evaluations which include designing and carrying out process evaluations and learning outcomes on an ongoing basis with various methods, analyzing the results of the evaluation of the process and learning outcomes for determine the level of mastery learning, and utilize the results of learning assessments to improve the quality of learning programs in general. Based on information from inclusive teachers explained that, "One of the obstacles faced in learning in inclusive schools is in evaluating learning, because often the results of students with special needs can't be assessed only from one test, must be repeated." Finally, teachers can develop students to actualize their various potentials, including facilitating students to develop various academic potentials, and facilitate students to develop various non-academic potentials.

\subsection{Personality competence}

Personality competence is a personal ability that reflects a personality that is steady, stable, mature, wise, and authoritative, be an example for students, and have good character. Sub competencies in personality competence include first, a stable personality includes acting in accordance with social norms, being proud to be a teacher, and having consistency in acting according to norms. This is supported by the teacher's explanation that, "In daily life the teacher who takes care of inclusive children must be patient and be an example, because they also imitate what we will do." Second, a mature personality displays independence in acting as an educator and has a work ethic as a teacher. Third, a wise personality is displaying actions based on the benefits of students, schools and society and showing openness in thinking and acting. Fourth, authoritative personalities include having behaviors that have a positive effect on students and having respected behavior. Fifth, noble character and can be an example includes acting in accordance with religious norms and having behavior that is emulated by students.

\subsection{Professional competence}

Professional competence is the mastery of extensive and in-depth learning material, which includes the mastery of curriculum material in school subjects and the scientific substance that houses the material, as well as mastery of the structure and methodology of the science. Mastery of the material includes, structure, concepts, and scientific thought patterns that support the lessons being taught. Mastery of competency standards is emphasized on the basic competencies of the development subjects being taught. The teacher's explanation from the interview results implies that, "For the field of teaching professionalism, specifically the teachers here are not yet fully recognized, because some teachers are non-inclusive teachers, so we teach based on experience and additional training provided."

In teacher professional competence, little by little also began to be directed to be able to develop creative learning materials, develop professionalism in a sustainable manner by taking reflective actions and utilizing information and communication technology (ICT) to communicate and develop themselves. The ability to use media is also seen as helping to understand children. It is also based on the explanation of one of the teachers, "Pictures can help students understand. Children who often see pictures repeatedly can begin to recognize and understand them."

\subsection{Social competence}

Social competence is the ability of teachers to communicate and socialize effectively with students, education staff, students' parents, and the surrounding community. Forms of social competence are the ability to be inclusive, act objectively, and not discriminate because of consideration of gender, religion, race, physical condition, family background, and family social status. Teachers' social competence can also be demonstrated by communicating effectively, emphatically, politely with fellow teachers, education personnel, parents, and the community. Furthermore, teachers in Indonesia are also required can adapt to teaching throughout Indonesia which has socio-cultural diversity. One key in this competency is the ability of communication. This was reinforced by the teacher's statement during the interview which stated that, "The most powerful communication used in this school is two-way communication. The reason is because with two-way communication students are able to respond to what is conveyed by the teacher, even though it is simple."

\subsection{The essence of teacher's experiences in teaching autistic children}

Learning for autistic children, according to a teacher is like teaching a normal child. The essence of the experience of teachers in providing learning to autistic children to answer two basic questions in this research are what types of minimum competencies that must be possessed and what learning models can be applied. There are at least two of the four competencies that must be possessed by teachers, namely pedagogical and social competencies. Other competencies such as professional competence and personality 
competence do not mean not important, but based on the statement of one of the teachers in inclusive schools that, "Considering teachers who have been teaching for a long time, they have been given training by senior teachers or the headmaster, so they have standards minimal service." Added by other teachers, that in addition to these competencies must also make experience as one of the forming of competencies, "Based on my experience, that teaching ability and personal closeness are key to autistic children being able to interact and communicate in the learning process."

Among the teaching methods that are currently considered suitable by inclusive teachers is giving material in an explanatory method, giving assignments in the form of practice, and providing intensive mentoring to students. Character education taught to autistic children includes the skills of reading and writing the Quran, communication skills, and skills to interact with peers and teachers. Teaching about religion is given by the explanatory method in class. This is done to train student concentration. This statement was confirmed by the teacher in the interview stating that, "In the explanatory method simple and clear sentences will be delivered. For example, "let's write," "let's read." This is done to stimulate their concentration.

The skill of reading and writing the Quran is carried out with continuous practice. Social skills in this case are the ability to interact and communicate also with practice and assistance. The teacher also gives direction to students to communicate with each other, then the teacher provides special assistance to students who are considered not proficient. Character education material in the form of religious studies, communication, and social interaction is provided in the form of explanatory, practices, and mentoring with the aim of students or autistic children having sufficient stock in later interacting with family and the surrounding environment. One teacher expressed his opinion during the interview, "If in the morning there is a ceremony and the morning greets, then after that students perform the Duha prayer in congregation. Usually, students are still guided to pray, because for the order of ablution 'they still have not memorized. The movements are also the same, so those prayers must still be guided, prayers after the Duha prayer. Then we have prayer reading activities for both parents and we will go to class. In class we also pray before learning, then read Iqra'. If by chance just during Ramadan, we add to the literacy. So, students are usually free to read any book after the Quran. After that, there are also memorization of short letters Juz 30. “... Although for prayer they still have to be guided, for example ablution and its movements, as well as prayer and its movement. Sometimes they just move, and we read their prayers, but it became a routine that they were also passionate about...".

\subsection{Learning model for character education in autistic children}

Before discussing the learning model for autistic children, according to the learning flow in the classroom, the following can be shown in Figure 2 about the specific flow of inclusive learning for autistic children. The learning process in autistic children based on the teacher's experiences begins with the stages of learning planning and learning implementation. There are two forms of learning for autistic children, picture exchange communication system (PECS) and applied behavior analysis (ABA). PECS is an approach to practice communication using verbal symbols [31]. PECS is designed and developed with the aim of helping to make it easier for autistic people to be able to communicate or express their wishes. This method uses the image as the main media, but it would be better if it presents a real object along with the availability of the image. The advantage of PECS is that the goals are clear and easy to understand, children are determined by their own, material is easy to get, and children can communicate with anyone [32].

Applied behavior analysis (ABA), can be interpreted as an applied science that studies and modifies the autistic person. In addition, it can be interpreted as knowledge that uses behavioral change procedures to help individuals build capabilities by measuring the values that exist in society [33, 34]. This method has rules and theories that apply, but does not make it difficult to apply in learning autistic children. The purpose of the ABA method is active two-way communication, socialization into the general environment, eliminating and minimizing unnatural behavior, teaching academic material, and self-skills [35]. Some methods in ABA, namely Facilitated Communication shows letters to express themselves, and the sign language method that uses the movements of the hands, body, face, and other body parts to communicate. For some children, this method becomes difficult because they experience obstacles in making the right movements.

One of the character learning activities is to strengthen and develop autistic children's communication by establishing good interpersonal relationships [36]. Furthermore, interpersonal relationships that can be done by autistic children are by teaching the relationship between friends, teachers, and God. Forms of prayer and motivating yourself are examples. The teacher provides assistance with how to carry out the Duha prayer before the start of learning. Not just an invitation, but the teacher participates in conducting the Duha prayer and some others guide their students in the implementation of the Duha prayer, 
because as is well known, autistic children must always be given guidance and direction [37]. It is also used to instill character education and form good character for students.

One of the teachers said that, "Even though no one ordered it, the children took the initiative to go to the mosque and pray Duha. Sometimes, we also want to see how sensitive they, so we deliberately don't give direction. Then after they went to the mosque, we were happy to mean they had a good initiative and we went to the mosque in part to guide the prayers in part to pray with the children. They also have even been able to become priests." Another teacher also added that, "Even for prayers they still need to be guided, for example ablution and its movements, as well as prayer and its movement. Sometimes they just move, and we read their prayers, but it became a routine that they were also passionate about. After praying we Duha prayer, then we pray for parents too."

Before starting the learning process, students are accustomed to pray. After praying, students then read the Iqro' according to their respective levels. Iqro' reading must still be guided by the teacher, usually by writing large Hijaiyah letters on the paper, if they have difficulty reading it or by writing the latin writing. One interesting thing about this school is the literacy program before learning. Therefore, after reading Iqro' students are required to read books with any theme and for those who cannot read, they only listen to their friends who read. The application of self-introspection as a form of self-evaluation is also carried out in the process of implementing these learning stages. At the time of observation, several events were found, for example when there was one student borrowing stationery to his friend and then returning it without saying thank you, the teacher immediately gave advice related to the courtesy of borrowing other people's things simply. The teacher asks, "Did you borrow your friend's eraser? Did you say thank you yet? Earlier your writing was wrong, after that borrow your friend's eraser, now your writing is correct. What do you have to do, hey? The response of the students was positive, he looked down as if evaluating himself whether he was wrong or not, then without getting the student's direction to his friend's table and say "thank you." Although it looks simple, but for autistic children it is a good achievement and is a form of communication with god, that he felt he had done the wrong thing and then he fixed it.

Communication has an important influence in learning autistic children. In the previous period the group learning model had been applied using the explanatory method when religious education subjects were in a room with one teacher as a communicator. Various autistic characteristics in one place, with a variety of communication skills as well, in fact unable to deliver the group's communication methods to run smoothly. There are students who initially focus, then get bored. In other corners there are also those who are preoccupied with their own world. Running and laughing without caring about learning. That is the picture of the group communication method in the Islamic religion learning that was once applied at the school. The experience was conveyed by a teacher who specifically teaches religious material. But back again to the intellectual abilities of each student, sometimes senior high school students are not superior to intellectual abilities compared to junior high school students. In fact, there are elementary school students whose intellectual exceeds the junior high school students. Based on that, it was concluded that such learning (explanatory method) was less effective, because their intellectual intelligence was different, so that there were students who understood what the teacher explained and some were just playing around. Meanwhile, the religious activities that are really carried out together are only the Duha and Dzuhur prayers in congregation, and even then we still have to guide.

The basic material in learning autistic children are reading and writing. In this reading process, students are given a book facility containing themes that will be discussed for later reading. For students who are not fluent in reading, the teacher will read it. The reading activity is then continued by writing down material that has been read in the student's writing book. The goal is that the material that has been read is increasingly embedded in the memory of students. But in truth, this process takes a long time. After finishing writing what is read, at this stage the teacher's role begins. The teacher explains the material that has been read and written by students. The explanation also lasts quite a long time, because it must use very simple language so that it is understood by students.

Furthermore, to determine the level of student understanding of the material, a question-and-answer process was carried out. This question and answer contain material that has been learned by students. In giving questions, the teacher must use question words that are simple and not convoluted, for example "Hey try asking mom, what the Hajj is?" The question must also be asked with an expression which means that the communicator is asking the communicant. Another learning process undertaken to strengthen children's abilities is intensive learning and repetitive learning. In the observations made, before learning with a new theme, the teacher repeats the learning material in the previous learning. The repetition is done by giving questions related to past themes, if the student is able to answer it means they already understands and still remembers the past material. However, if the student participant is unable to answer, then learning with a new theme will not be carried out, but will be replaced to repeat the material at the last meeting. The success 
of intensive learning can be seen in the Duha prayer activities, where students are able to carry out the Duha prayer at the usual time without receiving instruction.

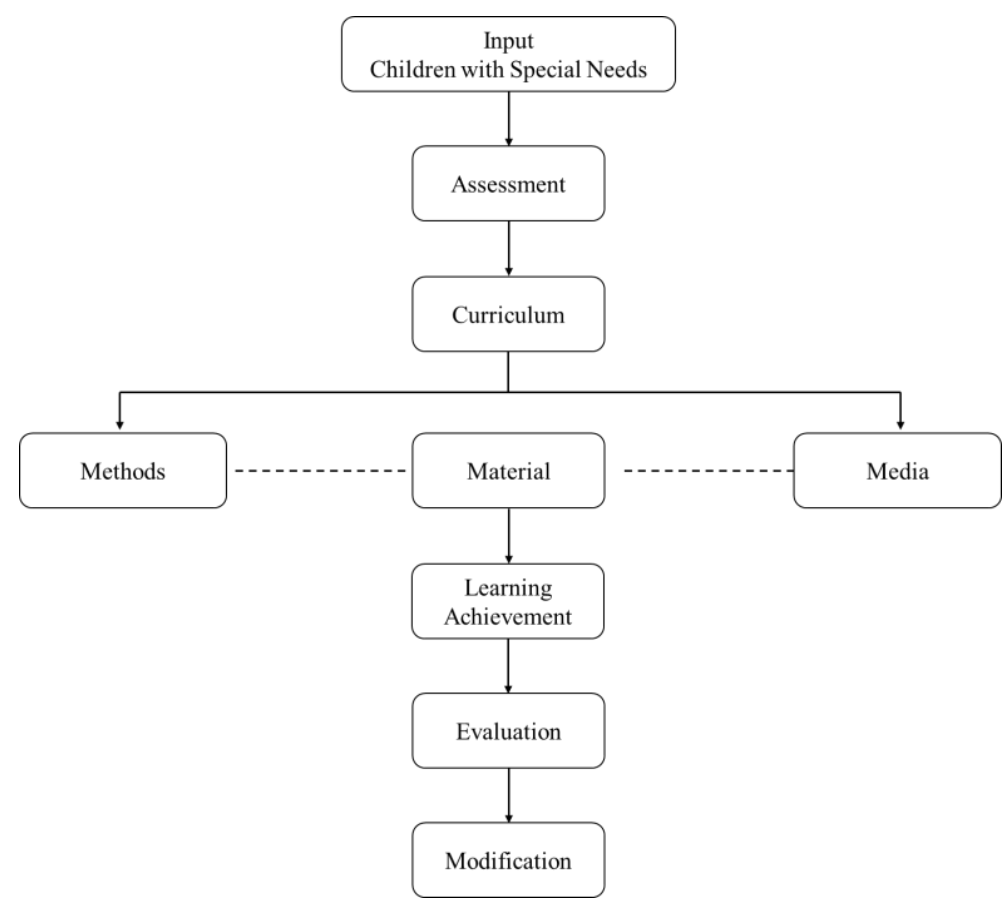

Figure 2. Special flow of inclusive learning for autistic children

\subsection{Supporting and inhibiting factors in character learning of autistic children}

The main supporting factor in character learning in autistic children are the availability of professional teacher graduates with provision of material and practice that has been certified, integrated curriculum, adequate infrastructure and facilities both in the form of classroom comfort, learning atmosphere, learning media in the form of audio visual. A similar opinion was conveyed by a senior teacher who stated in an interview that, "Ideally it is true that to teach in inclusive schools, it must be from graduates of the department of exceptional education. They already have minimal service standards and a lot of knowledge."

Meanwhile, the inhibiting factor in the learning process in autistic children are an internal factor, where the limited ability of the child itself. Many experts have agreed that an autistic child has an abnormality in the brain. The occurrence of these disorders causes children to be less sensitive to the environment. According to Sathyanesan, et al. [38], abnormalities in the brain, especially the cerebellum will impact on sensory processes, memory, and thinking, learning, and attention processes. It was strengthened from the results of the teacher's interview that, "The biggest obstacle in teaching is from the students themselves, because they have limitations in thinking, remembering, and inconsistency, the same goes to students too. Inconsistent going to school, if the holidays he has learned become forgetful...". The main problem for autistic children is a lack of focus. The teacher must have a strategy to be able to make autistic children focus in learning. Each teacher has a unique way so that their students can focus on learning. Uniquely, if the strategy used by one teacher is applied to other students, it will not have any effect. Vice versa, so it can be concluded that the student will obey the command if he already knows who the interlocutor is and matches the strategy used. One teacher explained that, "Inclusive children are like having their own world, so the focus is lacking and must always be constantly reminded to focus. Usually by being called and invited to communicate."

Factors that inhibit further learning externally is the lack of school facilities in learning. This is due to being a private school that funds school operational costs for itself, which requires a significant amount of funds. In addition to teachers who must prepare learning media, schools should also participate in providing adequate learning facilities, so that main objective of the learning process can be realized in stages. This was justified by the teacher that, "To make it easier there should be a medium (audio visual), but sometimes there are also children who don't want audio because it is noisy, visuals also don't want to. The lack of media will also affect the learning, also the professionalism of a teacher if teaching in a special school, means the 
teacher must know how to anticipate if there are undesirable things, and the teacher must know how to provide teaching for autistic children." The deficiencies in this facility are handled by the teacher by using direct practice in character education learning materials. As a result, the learning process requires high creativity from the teacher.

\section{DISCUSSION}

Character education is a compulsory material in Indonesian education. Character education can take the form of material about religious education, nationality, and others. According to Simpson, character is a set of one's internal commitments. Where someone has the nature and attitude carried out intensely [37]. Forms of character education teaching for autistic children in inclusive schools in Indonesia are grouped into 3 forms, namely explanatory, practices, and mentoring. In practice teacher competence has a lot of influence in the success of learning character education for autistic children. The ability of teachers to design learning materials, good two-way communication and intensive mentoring makes learning outcomes more leverage. Although the explanatory method is a conventional method that is centered on what is conveyed by the teacher, but in this method can lead students to learn to concentrate. This is important for autistic children. Intensity and increased communication will be able to stimulate the ability of autistic children [39]. One of the biggest obstacles of modern society is the emergence of characters that are not in accordance with the norms of surrounding communities such as obedience and law abiding, interacting in harmony with their environment $[40,41]$.

Communication as an important element in social competence turned out to have the most influence in the learning process of character education for autistic children. Communication is the process of delivering and receiving information, as well as a means of socializing. Delays in the development of communication and language can cause isolation, frustration, and decreased quality of life [42]. The development of communication and language is even more likely to be delayed for autistic children. Communication is a process of statement between humans, namely the process of delivering a message by the communicator to the communicant. Ideal communication describes the role as problem solver [43]. Communication is the process by which individuals use symbols in the form of written communication and oral communication that are closely related to essential life skills and desired educational out comes [44]. Thus, communication can be broadly defined as sharing experiences to some extent. Every creature can be said to communicate in the sense of sharing experiences, but specifically, the communication in question is human communication.

In accordance with learning that begins with the preparation of the material, the implementation of learning that uses certain methods, then learning in general can be interpreted as a learning and teaching process in which there is a process of transfer and exchange of knowledge. Because in the process, not only teachers are the source of knowledge, but students can also be used as information providers. They plan and implement all of their lessons together and solve problems in class [45]. In the learning process, a teacher must understand his position, understand also live the nature of learning and implement it when the learning process takes place. In addition, the teacher must also be good at creating a class atmosphere into an active and educative class. This is certainly very closely related to the ability and communication model applied by the teacher.

There are two factors that influence communication in the learning process, namely internal factors and external factors in this case are the sender and receiver [46]. Internal factors come from within the child, such as health, security, ability, and interests, while external factors are factors that come from outside the child, such as the cleanliness of the place and the environment. Before implementing learning there is one step that needs to be done, namely learning planning. Learning planning begins by screening out teachers who have the potential to become exceptional school teachers [47]. Teachers in providing effective teaching, of course must have the competence in teaching, as well as special education must require professional. In accordance with the special development program of the directorate of special education and special services Indonesia stated that one of the requirements in teaching autistic children is to find teachers who graduated from exceptional education departments or inclusion, so that when teaching meets minimum service standards [48].

However, this condition has several obstacles in the field, where there are not many teachers with such qualifications. The optimization of teachers in schools is done by conducting workshops and trainings, so that their ability to educate autistic children are no doubt based on existing experience. Next planning, teachers who are ready to give lessons in autistic schools, modify the existing curriculum so that it is suitable and appropriate for autistic students. Planning in this stage also has a big influence on what methods will be used during the learning process [49]. As explained earlier, education is centered on the competencies, knowledge, and skills that a student is expected to have after completing a program. Student assessment 
through a portfolio that provides a variety of evidence that demonstrates mastery of competencies [50]. The experience of teachers who teach for autistic children, they are creative by creating an individual education program which is an individual learning program that is used for each student they support. Supporting teachers are required to understand the characteristics possessed by the students they support, making it easier to provide learning in accordance with the characteristics of these students.

Learning media are also included in the learning planning list. In general, the media used to educate autistic children is with icons and images or visuals that represent objects [51]. The teacher prepares the media to be used in the learning process in the form of pictures, learning books, paper media, colored pencils, and presents real examples of the themes to be discussed. For example, learning with a commendable moral theme, the teacher prepares a picture of a child helping a parent, then students are asked to color the drawing with color pencils that are deliberately not yet sharped. Students automatically sharpen the color pencil to be able to color. At the end, the teacher asks students to discard the color pencil sharpener. After that, the teacher explained that what had been done by the students was an example of commendable behavior included in the strengthening of character education.

\section{CONCLUSION}

This research illustrates the experience of teachers in teaching autistic students about character education materials. This research describes teaching models, methods, and various types of other competencies that support teaching character education such as communication skills. This research also found that teaching conducted by teachers has characteristics and methods that vary according to the abilities of autistic children. There are two forms of learning for autistic children which have been proven to be successful, namely picture exchange communication system (PECS) and applied behavior analysis (ABA). An effective communication model is two-way communications in the form of face to face between the teacher and students. The concept of one teacher with one student and repeated it is proven to make learning easier and more effective for autistic children. However, in this research there are no specific guidelines for assessing the level of learning success for autistic children.

Supporting factors in the success of autistic children learning lies in the ability of teachers who have been certified, creativity, and innovation of teachers in their learning methods as well as patience and emotional closeness with students. This is proven by the discovery of the strategies of one teacher to another different and can only be applied in each class. Meanwhile, the biggest inhibiting factor is from the children themselves because of their limited abilities. Therefore, further studies are expected to design specific assessment models to measure success in learning for autistic children. This special assessment model is useful for evaluating the degree to which understanding is gained by students. This is important for schools to improve the quality of their graduates. The results showed that the experience, skills, creativity, and communication skills of teachers are competencies that must be possessed by teachers, especially in inclusive schools. This competency component is important for teachers before entering in inclusive schools. The many demands of the success of character education, especially for autistic children, require strong cooperation within the stakeholder environment, namely schools and teachers. School policies can take the form of curriculum, infrastructure, and facilities. The teacher is needed in his competence in the teaching process.

\section{ACKNOWLEDGEMENTS}

The authors thank the respondents who participated in this research. Authors also thank the lecturers of the graduate school of Yogyakarta State University who have guided this research.

\section{REFERENCES}

[1] H. Putranta and I. Wilujeng, "Physics learning by PhET simulation-assisted using problem based learning (PBL) model to improve students' critical thinking skills in work and energy chapters in MAN 3 Sleman," Asia-Pacific Forum on Science Learning and Teaching, vol. 20, no. 1, pp. 1-20, 2019.

[2] M. L. Sigmon, et al., "Using children's picture books about autism as resources in inclusive classrooms," The Reading Teacher, vol. 70, no. 1, pp. 111-117, 2016.

[3] Republic of Indonesia, "Constitution of the Republic of Indonesia Number 20, 2003, concerning the National Education System," 2003.

[4] I. Robeyns, "Conceptualising well-being for autistic persons," Journal of Medical Ethics, vol. 42, no. 6, pp. 383-390, 2016.

[5] A. Graham and M. Frasier-Robinson, "Autism spectrum disorder: a guide to the latest resources," Reference \& User Services Quarterly, vol. 55, no. 2, pp. 113-118, 2015. 
[6] J. S. Singh, "Narratives of participation in autism genetics research," Science, Technology, \& Human Values, vol. 40, no. 2, pp. 227-249, 2015.

[7] J. Richler, "Autism grows up," Scientific American Mind, vol. 26, no. 1, pp. 36-42, 2015.

[8] S. Healy, et al., "I'm not in this alone" the perspective of parents mediating a physical activity intervention for their autistic children spectrum disorder," Research in developmental disabilities, vol. 83, pp. 160-167, 2018.

[9] C. Sosnowy, et al., "Setbacks and successes: How young adults on the autism spectrum seek friendship," Autism in Adulthood, vol. 1, no. 1, pp. 44-51, 2019.

[10] J. Cook, "From movement kinematics to social cognition: the case of autism," Philosophical Transactions of the Royal Society B: Biological Sciences, vol. 371, no. 1693, pp. 20150372, 2016.

[11] A. Moore and M. Clarke, "'Cruel optimism': Teacher attachment to professionalism in an era of performativity," Journal of Education Policy, vol. 31, no. 5, pp. 666-677, 2016.

[12] M. M. Iswari, et al., "Character education for the 21 st century in developing the careers of children special needs in vocational inclusive school," 5th International Conference on Education and Technology (ICET 2019), Atlantis Press, 2019.

[13] H. Putranta and J. Jumadi, "Physics teacher efforts of islamic high school in Yogyakarta to minimize students' anxiety when facing the assessment of physics learning outcomes," Journal for the Education of Gifted Young Scientists, vol. 7, no. 2, pp. 119-136, 2019.

[14] H. Stockinger, "Developing spirituality-an equal right of every child?" International Journal of Children's Spirituality, vol. 24, no. 3, pp. 307-319, 2019.

[15] R. Zidny, et al., "A multi-perspective reflection on how indigenous knowledge and related ideas can improve science education for sustainability," Science \& Education, vol. 29, no. 1, pp. 145-185, 2020.

[16] E. Ergin and H. Bakkaloğlu, "Examination of in-classroom transitions in inclusive preschool classrooms," Early Child Development and Care, vol. 189, no. 5, pp. 820-834, 2019.

[17] J. Mailool, et al., "Lecturers' experiences in teaching soft skills in teacher profession education program (TPEP) in Indonesia," Problems of Education in the 21st Century, vol. 78, no. 2, pp. 215-234, 2020.

[18] S. W. Ng and Y. W. Kwan, "Inclusive education teachers-strategies of working collaboratively with parents of children with special educational needs in Macau," International Journal of Educational Reform, vol. 29, no. 2, pp. 191-207, 2020.

[19] H. J. Sticker, A history of disability. University of Michigan Press, 2019.

[20] A. E. Jones, et al., "A natural history of repetition,” Journal of Montessori Research, vol. 5, no. 2, pp. 15-44, 2019.

[21] T. E. Davis III, et al., Handbook of autism and anxiety. New York: Springer publications, 2014.

[22] N. Haslam, et al., "Categories versus dimensions in personality and psychopathology: A quantitative review of taxometric research," Psychological medicine, vol. 42, no. 5, pp. 903-920, 2012.

[23] A. Saatcioglu and T. M. Skrtic, "Categorization by organizations: Manipulation of disability categories in a racially desegregated school district," American Journal of Sociology, vol. 125, no. 1, pp. 184-260, 2019.

[24] T. Q. Le, et al., "Application of Change management theory to command new teaching activities in high schools," International Journal of Innovation, Creativity and Change, vol. 11, no. 2, pp. 557-568, 2020.

[25] C. Moustakas, Phenomenological Research Methods. Sage Publications, 1994.

[26] J. W. Creswell, Qualitative Inquiry \& Research Design: Choosing Among Five Approaches, 2nd ed. Sage Publications, 2007.

[27] J. W. Creswell, Research Design, Qualitative, Quantitative and Mix Methods Approaches, 3rd ed. Sage Publications, 2009.

[28] Ministry of Education and Culture, Regulation of the Minister of Education and Culture of the Republic of Indonesia Number 157 of 2014 concerning Special Education Curriculum, 2014.

[29] Republic of Indonesia, "Constitution of the Republic of Indonesia Number 14, 2005, concerning teachers and lecturers," 2005.

[30] J. B. Ganz, et al., "The picture exchange communication system (PECS): A promising method for improving communication skills of learners with autism spectrum disorders," Education and Training in Autism and Developmental Disabilities, vol. 47, no. 2, pp. 176-186, 2012.

[31] A. Jurgens, A. Anderson, and Dennis W. Moore, "Maintenance and generalization of skills acquired through picture exchange communication system (PECS) training: a long-term follow-up," Developmental neuro rehabilitation, vol. 22, no. 5, pp. 338-347, 2019.

[32] S. A. S. Arifin, et al., "The factors that influence of reading ability the Hijaiyah alphabet on pre-school children," Journal for the Education of Gifted Young Scientists, vol. 8, no. 2, pp. 667-680, 2020.

[33] F. Mohammadzaheri, et al., "A randomized clinical trial comparison between pivotal response treatment (PRT) and structured applied behaviour analysis (ABA) intervention for autistic children," Journal of Autism and Developmental Disorders, vol. 44, no. 11, pp. 2769-2777, 2014.

[34] E. A. Boutot and K. Hume, "Beyond time out and table time: Today's applied behaviour analysis for students with autism," Education and Training in Autism and Developmental Disabilities, vol. 47, no. 1, pp. 23-38, 2012.

[35] L. L. McIntyre and P. K. Zemantic, "Examining services for young autistic children spectrum disorder: Parent satisfaction and predictors of service utilization," Early Childhood Education Journal, vol. 45, no. 6, pp. 727-734, 2017.

[36] T. W. Simpson, "Trustworthiness and moral character," Ethical theory and moral practice, vol. 16, no. 3, pp. 543-557, 2013. 
[37] A. Sathyanesan, et al., "Emerging connections between cerebellar development, behaviour and complex brain disorders," Nature Reviews Neuroscience, vol. 20, no. 5, pp. 298-313, 2019.

[38] B. N. Beaver, et al., "Self-reinforcement compared to teacher-delivered reinforcement during activity schedules on the iPod touch," Education and Training in Autism and Developmental Disabilities, vol. 52, no. 4, pp. 393-404, 2017.

[39] K. Dineen, "Kant, emotion and autism: towards an inclusive approach to character education," Ethics and Education, vol. 14, no. 1, pp. 1-14, 2019.

[40] H. Putranta and H. Kuswanto, "Improving students' critical thinking ability using problem based learning (PBL) learning model based on PhET simulation," SAR Journal, vol. 1, no. 3, pp. 77-87, 2018.

[41] S. M. Bruce and C. Borders, "Communication and language in learners who are deaf and hard of hearing with disabilities: Theories, research, and practice," American Annals of the Deaf, vol. 160, no. 4, pp. 368-384, 2015.

[42] C. A. Zetina, et al., "Solving the optimum communication spanning tree problem," European Journal of Operational Research, vol. 273, no. 1, pp. 108-117, 2019.

[43] H. C. A. Kistoro, et al., "Islamophobia in education: perceptions on the use of veil/niqab in higher education," Indonesian Journal of Islam and Muslim Societies, vol. 10, no. 2, pp. 227-246, 2020.

[44] H. Putranta, "Synthesis of the cognitive aspects' science literacy and higher order thinking skills (HOTS) in chapter momentum and impulse," Journal of Physics: Conference Series, vol. 1397, no. 1, 2019.

[45] R. Emanuel, "The true story of oral communication education in Alabama: A case of academic discrimination?" The Journal of General Education, vol. 65, no. 1, pp. 20-35, 2016.

[46] S. B. Cross and A. H. Dunn, ""I didn't know of a better way to prepare to teach": A case study of paired student teaching abroad," Teacher Education Quarterly, vol. 43, no. 1, pp. 71-90. 2016.

[47] J. Pollock, "Social externalism and the problem of communication," Philosophical Studies, vol. 172, no. 12, pp. 3229-3251, 2015.

[48] C. M. Evans, et al., "Exploring K-12 competency-based education implementation in the Northeast States," NASSP Bulletin, vol. 103, no. 4, pp. 300-329, 2019.

[49] E. Latipah, et al., "Elaborating motive and psychological impact of sharenting in millennial parents," Universal Journal of Educational Research, vol. 8, no. 10, pp. 4807-4817, 2020.

[50] E. Latipah, et al., "The effects of positive parenting toward intolerance in pre-school children," International Journal of Early Childhood Special Education, vol. 12, no. 2, pp. 137-146, 2020.

[51] E. Latipah, et al., "How are the parents involvement, peers and agreeableness personality of lecturers related to self-regulated learning?" European Journal of Educational Research, vol. 10, no. 1, pp. 413-425, 2021. 